\title{
Beyond being present: learning-oriented leadership in the daily work of middle managers
}

\author{
Marianne Döös, Peter Johansson \& Lena Wilhelmson ${ }^{1}$
}

\begin{abstract}
.
Purpose - In their daily work, managers influence the organisation's learning conditions in ways that go beyond face-to-face interaction. Neither the influencer nor those influenced are necessarily aware that they are engaged in learning processes. This paper contributes to the understanding of learning-oriented leadership as being integrated in managers' daily work. The particular focus is on managers' efforts to change how work is carried out through indirect acts of influence.

Design/methodology/approach - The research was part of a larger case study. The data set comprised interviews with nine middle managers about ways of working during a period of organisational change. A learning-theoretical analysis model was used to categorise managerial acts of influence. The key concept concerned pedagogic interventions.

Findings - Two qualitatively different routes for indirect influence were identified concerning social and organisational structures: one aligning, that narrows organisational members' discretion, and one freeing, that widens discretion. Alignment is built on fixed views of objectives and on control of their interpretation. The freeing of structures is built on confidence in emerging competence and involvement of others.

Research limitations/implications - The study was limited to managers' descriptions in a specific context. An issue for future research is to see whether the identified categories of learning-oriented leadership are found in other organisations.

Practical implications - The learning-oriented leadership categories cover a repertoire of acts of influence that create different learning conditions. These may be significant for the creation of a learning-conducive environment.

Originality/value - The study contributes an alternative way of thinking about how work conditions are influenced that impact on learning in organisations. Managerial work that creates conducive conditions for learning doesn't need to be a specific task. Learning-oriented elements are inherent in aspects of managerial work and managers' daily tasks can be understood as expressions of different kinds of pedagogic intervention.
\end{abstract}

Keywords Learning, Learning-oriented leadership, Leadership, Pedagogic intervention, Middle manager, Workintegrated learning

Paper type Research paper

\section{Introduction}

'Beyond being present' paraphrases the title of Hooijberg and colleagues' book Being There Even When You Are Not (Hooijberg et al., 2007) and relates to our interest in how managerial work can bring about learning conditions in an organisation. Work-integrated learning (Ellström, 2001) - i.e., learning that comes as an inherent part of one's daily work (Döös, 2007) - is a term used to describe informal learning that affords opportunities for development in organisations, as well as research questions that seek to understand how conditions for such learning are formed through managers' daily work. Eraut's empirical studies consistently show that most informal learning occurs "as a by-product of normal working processes" (Eraut, 2011, p. 186; orig. italics). This points to the importance of studying how conditions for learning processes may also be created when there is no explicit aim to facilitate learning. Following Eraut's (2011) classification of learning processes according to whether their principal intention is working or learning, our focus lies where the primary intention is working. Therefore, this paper is based on two basic assumptions: that, in their daily work, managers influence the learning conditions in the organisation by their

\footnotetext{
${ }^{1}$ The authors appear in alphabetical order and each made an equal contribution to the work.
} 
forming of organisational and social structures (i.e., beyond face-to-face interaction), and that neither the influencer nor those being influenced are necessarily aware that they are engaged in learning processes.

The aim of this paper is to contribute to the understanding of learning-oriented leadership as being integrated in managers' daily work. The empirical focus is on middle managers' efforts to influence ways of working in their organisation as a means to stay competitive in the global software communication market. Previous research has enhanced the knowledge about learning-committed leadership (Ellinger, 2005), about attempts to intentionally influence both learning (e.g., Doornbos et al., 2004; Ellinger \& Bostrom, 2002; Noer, 2005) and personal competence (Bredin \& Söderlund, 2007), often with a focus on face-to-face communication and with the manager as an interaction partner (Koopmans et al., 2006). This paper, by contrast, analyses managers' efforts to influence how work is carried out through indirect acts of influence, i.e., through indirect pedagogic interventions that may change the conditions for experiential learning (Döös \& Ohlsson, 1999). Two research questions are used; the first descriptive and the second analytical:

- How do the middle managers attempt to change ways of working in their organisation?

- How can this be understood as learning-oriented leadership that forms conditions for work-integrated learning?

We then go on to describe previous studies and lines of argument before detailing the specific learning theoretical basis used in the analysis of the empirical data. After a description of our methods, the findings are presented and discussed.

\section{Previous research}

In the literature about learning in organisations, there has in recent times been an emphasis on creating opportunities for learning through making the workplace a learning environment (Billett, 2004; Ellström et al., 2008; Illeris, 2004; Johansson, 2011). Previous research also points to the role of leadership in relation to the development of workplace learning environments (e.g., Agashae \& Bratton, 2001; Amy, 2008). According to Yukl (2009), creating conditions for innovation and collective learning is one of the greatest challenges of leadership. Following Yukl, we define leadership as the "process of influencing others to understand and agree about what needs to be done and how it can be done effectively, and the process of facilitating individual and collective efforts to accomplish the shared objectives." (Yukl, 2002, p. 7). This definition introduces the ideas of process and collectivity, which are relevant in this context; they also point to leadership as creating favourable conditions for learning and thus the accomplishment of organisational goals.

To be appointed as a line manager in the organisational hierarchy involves the exercise of leadership (Tengblad, 2012). In line with Holmberg and Tyrstrup (2012), we see leadership as being integrated in managers' tasks, i.e., managerial leadership; for this reason, we use the terms manager and leader interchangeably in this paper. Furthermore, we use influence as a term to describe the intentional acts that managers described to us, whereas our theory-based 
concept used for the analysis of such acts is indirect pedagogic interventions (see theory section). In this paper, we do not use the term 'indirect leadership', which often refers to a structural distance between leaders and followers (Avolio et al., 2004) that shows how leaders influence "individuals two or more hierarchical levels below" (Larsson et al., 2005, p. 216). To our knowledge, both the literature about managerial work and that about indirect leadership are particularly limited when it comes to explicating managers' acts of influence as condition-creating interventions in work-integrated learning processes.

During the last decade, there has been a growing body of literature on managerial facilitation of learning that has contributed to different, only partly connected, streams of knowledge. Of importance here are a number of human resource-based studies concerned with the managerial facilitation of employees' learning (e.g., Beattie, 2006; Bredin \& Söderlund, 2007; Macneil, 2001; Noer et al., 2007), with an emphasis on informal learning from a noneducational perspective (Doornbos et al., 2004). The emphasis on informal learning is shared by studies that belong to the stream of adult-learning and workplace-learning literature, examples of which are Ellström (2010) and Wallo (2008). Both Wallo (2008) and Warhurst (2013) develop the idea of leadership in relation to learning that is based on managers' beliefs about learning and how to enable it. Furthermore, there are categorisations of what managers do when aiming to facilitate learning when present face-to-face (Beattie, 2006) and in their coaching (Noer et al., 2007). For example, Beattie presents a nine-level pyramidal model (a hierarchy of facilitative behaviours), where the base is the commonest category 'caring' and the top the least frequent 'challenging'. Caring behaviours are described, for example, as giving aid or courage, relieving anxiety or being easy to approach, while challenging behaviour is stimulating people to stretch themselves. These facilitative behaviours are also related to a framework of learning culture. By studying managers as facilitators of learning through the lens of beliefs - i.e., when a manager perceives that he or she is facilitating learning - empowering and facilitating behaviours were identified (Ellinger et al., 1999). Furthermore, positive as well as negative organisational contextual factors have been identified (Ellinger \& Cseh, 2007). On the positive side, there are two themes: learningcommitted leadership/management and an internal culture committed to learning. The four negative factors were: structural inhibitors, lack of time (heavy workloads), an overwhelmingly fast pace of change, and negative attitudes.

Harman (2011) and Boud and Solomon (2003) have empirically shown that some managers and other employees dislike being categorised as learners. Other studies have explored the difficulties that some managers experience in integrating their managerial identity with the role of a facilitator of learning (e.g., Ellinger \& Bostrom, 2002). The role of facilitator of learning is described as being different from managers' daily work tasks, and from this comes a resistance that has to be overcome if managers are to consciously act as facilitators of learning (Ellinger et al., 1999). Additionally, Ellinger et al. state that the responsibility for "employees' learning and development has been increasingly devolved to the managers" (Ellinger et al., 2003, p. 435). In sum, this points to a risk of bias when explicitly interviewing people about how learning is facilitated, how learning conditions are created and so on. The risk is that the beliefs interviewees hold about learning filter their descriptions of how to bring 
about suitable conditions for learning. The choice to use critical incident technique - which is manifest in several previous studies (Beattie, 2006; Ellinger \& Cseh, 2007; Koopmans et al., 2006) - may be interpreted as a way to deal with this risk. Beliefs are defined as "closely held assumptions or generalizations about the world that guide reasoning and action" (Ellinger, 1997, as cited in Ellinger \& Bostrom, 2002, p. 148). In this study, we did not want such assumptions about learning to affect the data. Therefore, and contrary to several previous studies about managerial facilitation of learning (e.g., Amy, 2008; Wallo, 2008; Warhurst, 2013), we deliberately did not interview managers about learning. Furthermore, Eraut stresses the importance of managers' role in supporting learning, and his typology of learning modes indicates that "learning opportunities in the workplace depend on both the organisation of work and good relationships" (p. 195).

In sum, the empirical knowledge that exists about managers' importance for employees' learning largely builds on studies where facilitation of learning has been asked for explicitly, and studies where the positive, enabling side of face-to-face communication is the focus. There are fewer studies that deal with the issue of how to lead learning emerges in the daily work of managers and with the forming of learning conditions beyond the use of face-to-face communication and being a present interaction partner.

\section{Learning theoretical point of departure}

The theoretical foundation of this paper is experiential learning theory (ELT) (Kolb, 1984). This theory is originally about individual learning. It has been used and developed in many studies of both individual learning and also of collective learning in teams and networks (e.g., Döös \& Wilhelmson, 2011; Fejes \& Andersson, 2009; Ohlsson, 2013) as well as organisational learning (Dixon, 1994; Döös et al., 2015). We find ELT useful in problematising and conceptualising informal learning processes. Following Ellström (2011), we conceptualise learning in work "contrary to much current research in this field" [...] "neither as a social process inseparable from work practices nor as a purely cognitive process" (p. 105). Thus, there exists a significant body of research literature on informal learning at work that details how people learn when working individually and collectively.

Learning is the process through which people change their ways of thinking and/or acting and, when work-integrated, it is the process that generates individual and relational competence (Döös, 2007). Kolb (1984) defines experiential learning as "the process whereby knowledge is created through the transformation of experience" (p. 38). His emphasis is rather on the process than on the content or outcome (Kolb \& Kolb, 2005, 2010; Kolb, 1984). This paper draws on ELT's constructivist roots, thereby stressing the active contributions of a learning subject (usually an individual or a group) to what is learnt, and emphasising that learning occurs as a process of interaction between people and situations (Schunk, 2004). Also essential is Löfberg's early problematisation of the relationship between context and individual (Löfberg, 1976), which posits that the individual constructs knowledge on the basis of his or her interpretation of the conditions afforded (see Gibson, 1979; Reed, 1993 for the concept of affordance). His contribution addressed the issue of the duality of individual and social views of learning, which is still being discussed in the research literature (e.g., Ellström, 2011; Hodkinson et al., 2008). Löfberg defines the learning individual as a 
meaning-making subject who learns in relation to tasks and in action, and in interaction with both the physical and social worlds. In accordance with ELT, we regard learning as an actionbased process that changes the learner's way of thinking and/or acting. This leads to an understanding of learning as a work-integrated by-product of people's carrying out of tasks, and means three things: first, that people don't have to be aware of the fact that they are learning. Secondly, learning is not bounded to certain training activities, but is ongoing in daily working life, which means that managerial acts of influence can be analysed as opportunities for learning and as constituting a particular learning environment. Thirdly, learning occurs through an interplay between the affordances of the workplace and individuals' readiness to learn (Löfberg, 1989) where different types of learning are enhanced under different contextual circumstances (Johansson, 2011). In all their actions, people continuously construct and reconstruct their own and others' conditions for learning. Actions are performed in situations with varying limitations and possibilities where an individual's acts grow out of how the specific situation is perceived (Suchman, 1987). The term acts in this paper refers to something a human intentionally does. The outcome of these acts may be intended (results) or non-intended but following from the act (consequences) (Reason, 1990).

The concept of learning-oriented leadership is used to capture managers' endeavours to influence work, and is defined as interventions in learning processes that are integrated in the carrying out of work tasks (Wilhelmson et al., 2013). Döös and Ohlsson (1999) make a distinction between two types of pedagogic interventions: direct and indirect. This distinction is essential to understand how we analysed the data. Direct pedagogic interventions use communication as the means to influence people's conceptions, e.g., telling a teacher in a school that it is important to teach in collaboration. Such an intervention is easy to make, but the effect on action is most likely limited. Indirect pedagogic interventions influence acts and conceptions via changed environmental preconditions, e.g., changing a school's timetable so that two teachers are responsible for the teaching of each lesson. Indirect pedagogic interventions concern changes in the organisational context (the work environment) and have long been key in preventing workplace accidents and risky behaviours as they are more powerful in addressing human errors (Reason, 1990; Sundström-Frisk, 1996). While face-toface communication intervenes directly in individuals' meaning context, changes in the local work environment form new concrete experiences that bring about related thinking (Döös \& Ohlsson, 1999). Thus, the distinction between direct and indirect pedagogic interventions is based on the means used in an intervention, i.e., verbal communication or changes in the organisational context. Another dimension of pedagogic interventions concerns whether the interventions narrow or widen discretion. Ellström (1992) distinguishes between discretion (as degrees of freedom) where specific targets and expected ways of working are given, and discretion where space is afforded for individual actors to be part of the framing of tasks and ways of working.

\section{Method}

The research behind this paper was part of a larger case study about organisational learning (Döös et al., 2015; Wilhelmson et al., 2013). The study was performed using qualitative methods and was done at a time of large-scale changes in the organisation's ways of working; 
these changes were caused by a perceived need among senior and middle management to improve the connectivity and flexibility of products as well as people, and better meet customer demands. The study relies on abductive reasoning (Fann, 1970) and analytical generalisation (Firestone, 1993; Yin, 1989) within a chosen theoretical perspective (Döös \& Wilhelmson, 2014). Below, the choice of organisation and managers is explained, thereby addressing the issue of what this case represents (Yin, 1989). Also, the methods of data collection and analysis are described, and a brief contextualisation of the case study is provided to facilitate the reader's understanding of the findings.

\section{Choice of organisation and managers}

The case study was a global organisation within the software communication industry, where competition is sharp. The data collection was conducted in a research and development (R\&D) unit with approximately 1,200 employees (mostly engineers working as coders, designers, testers, and managers) divided into nine sub-units with local sites in a number of countries, but with its main activities in Sweden. The unit belonged to a larger R\&D department with some 5,000 employees. The 5,000-person department is referred to here as Ypsilon, and the 1,200-person unit as Zeta. The organisation was chosen as a case because it was a large established corporation in the software communication industry facing highly competitive and fast-developing new companies in Asia. This pressure had necessitated the full use of the company's highly skilled leadership and organisation and, at the time of the study, the senior and middle managers in Ypsilon were working intensely to make the new ways of thinking and working cross the boundaries between the many units and sub-units. During the data collection, an opportunity to get access to relevant data presented itself as the managers of Zeta worked to understand how they could connect organisational parts in new ways to support their ambition to change mind-sets and ways of working. This is why Zeta and the management team of Zeta were chosen for the analysis of this paper. These changes were also related to discussions and mutual influence processes in Ypsilon's apex and its management team, of which Zeta's top manager was a part.

\section{Data collection and analysis}

Braun and Clarke (2006) make a distinction between 'data corpus' - the full amount of data collected - and 'data set', i.e., the specific part of a data corpus that is analysed for a specific aim. The full data corpus of this study consists of: transcriptions from 24 individual semistructured interviews (1-2.75 hours) with 21 middle managers and some senior managers of Ypsilon, field notes from talks and visits, observations at four regular management team meetings, and five observations of other types of meeting where these managers met. The data corpus is here used to contextualise the analysed material. The data set analysed for this paper is comprised of interviews with nine managers (A-I), all from the management team of Zeta (the manager, his deputy manager, six middle managers and one programme manager). These middle managers (seven men and two women) all had long experience (10-31 years) within the corporation and also considerable latitude for making decisions. In the findings section, brief and slightly edited quotations from these interviews are included. The managers are kept anonymous and are only distinguished by code letters. Also, two other middle managers in Ypsilon are quoted below in the contextualisation of the case. 
The interviews purposely did not contain questions about learning, but rather concerned work tasks and ways of working during a period of organisational change. The aspect of learning is brought in by the theoretical perspective employed in the data analysis (see e.g., Döös \& Wilhelmson, 2014). As most data was collected during a period when the managers were trying to bring about change for the corporation to remain competitive, our interviews contain much information about their efforts to coordinate and influence work. The interviews with the middle managers of Zeta were transcribed verbatim (average 21 pages per interview, of between 8,900 and 18,000 words). They were then read and discussed by all three researchers as part of a process to produce condensed documents (3-6 pages per interview) with a focus on what the managers said about their and the organisation's ways of working. The learningtheoretical basis of the analysis departed from the distinction between direct and indirect pedagogic interventions (Döös \& Ohlsson, 1999), which is detailed in the theory section. On that basis, and for each interview, a protocol was set where accounts of both direct and indirect acts of influence were specified. Of approximately 320 accounts, three quarters were related to indirect acts of influence. Indirect pedagogic interventions were searched for as managerial acts of influence that strived towards changing the organisational context, thus producing changed conditions for work-integrated learning. Early in the analysis, a distinction emerged between examples where managerial acts either narrowed or widened discretion (Ellström, 1992). As the focus of this paper lies on indirect pedagogic interventions, it is the two quadrants B and D that are further developed in the findings section (see Figure 1). The explanation of the dimension of Figure 1 are found in the theory section. 


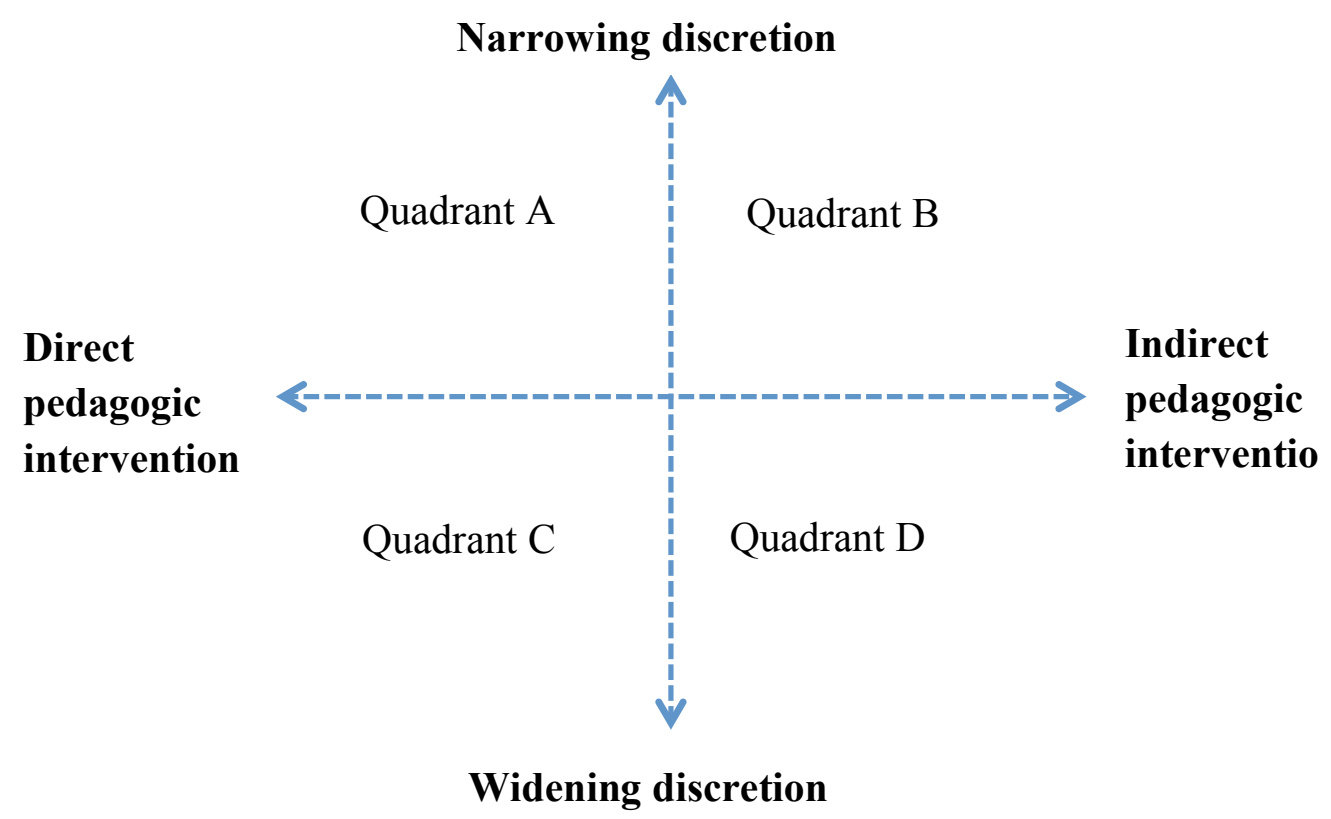

Figure 1. Analysis model for the categorisation of managerial acts of influence.

\section{Contextualising the case}

Here follows a brief contextualisation, where the last decade of the corporation's history is explained. Around the turn of the millennium, at the burst of the IT-bubble, the corporation's customers could not afford to buy its products, and the number of staff was reduced by a third to a half in the years that followed. In the autumn of 2008, the corporation had recovered, yet not fully. Some good signs were that it was in profit again, small innovation cells were started, and some managers managed to free up money for risk taking:

In the difficult years many managers became too obedient, so I think it is good that he dares a bit, we may get back a little civil disobedience. (L)

Part of the problem is that during the downturn, a lot of people [...] learned the behaviour of predictability and quality, and we have to kind of unlearn that a little bit, not completely because we need to keep that base, the [corporation] brand. (M)

Two years later, on our return for the main data collection in the autumn of 2010, there were islands of early adopters of a variety of 'new agile ways of working', , alongside the usual focus on delivery with quality in operational technology development. Through cooperative processes, the middle managers of Ypsilon were working to anchor these new agile ways of working both within and across sub-units - the description of managerial influence presented in the findings section is based in this period. In Ypsilon, this was regarded as a bold, largescale experiment with an uncertain outcome.

\section{Findings}

The middle managerial work at the unit included a number of tasks where the managers intended to influence the ways of working. By focusing on the managers' statements about

\footnotetext{
${ }^{2}$ A group of software development methodologies, where requirements and solutions evolve through iterations and incremental development between people with different functional expertise.
} 
how they acted to influence, empirically based categories of learning-oriented leadership were generated. A quote from one of the managers illustrates their overall ambition:

Traditionally, when we reorganise, the ways of working of the individual employee remain fairly stable ... but now we want to bring about changes in these ways of working, so there is not much that remains stable right now, as we kind of want to shake up from all perspectives. (D)

We identified indirect acts of influence that concerned changes of work conditions through pedagogic interventions in two types of structure in the organisation: organisational structures, i.e., reporting and responsibility lines in the formal hierarchy of organisational subunits; and social structures grounded in habits and previous decisions (e.g., norms, rules, procedures). We identified acts intended to align structures and acts intended to free structures. Below, each category is introduced with two-to-three quotes that exemplify the managerial acts of influence of that category. These quotes are then briefly explained, and a brief generalised interpretation of the category is presented.

\section{Aligning structures}

The middle managers described a need to align work in the organisation and used different means in trying to succeed. The alignment concerned both social structures (e.g., institutionalised norms, rules) through imposing requirements that would influence ways of working, and organisational structures as a redesign of the organisation chart or of the principles behind team composition.

\section{Aligning social structures - setting requirements to influence ways of working}

\footnotetext{
We set individual goals for the employees which, in somewhat fluffy terms, ask you during the year to work with one person in our organisation who is unknown to you. (A)

We prepare and book management reviews that we hold with all our organisation units once a year ... where we go through status ... it normally takes three, four hours and they tell about their activity, good things and bad things, and evaluate themselves on a range of issues. Mostly they tell you about ways of working ... There is a standard agenda where the actions points of the previous year are reviewed ... And they have a checklist where they colour-code themselves on how for example they cooperate with others, good practices is something we talk about for example, do you share good things that you develop and do you take in new things? (C)
}

The above quotes from two managers exemplify how this organisation works by setting demands and goals that are followed up at both individual and organisational levels. The first quote is an expression of the need to use more of the existing internal competence and methods across intra-organisational boundaries. In the second quote, one manager mentions systematic visits from the top manager of Zeta, the deputy manager, the HR-specialist and others during which, with the help of well-developed routines, they scrutinise all sub-units.

In their work with managing staff and each other, the middle managers said that they make and implement decisions that influence what is done and how it is expected to be done, that is, they set requirements to influence the ways in which work is carried out. The setting of requirements stretches beyond direct interaction and communication, but it may, of course, need communication in order to be carried out. However, the mechanism here is not to convince or invite by direct communication; the mechanism instead relies on the decisions 
made, the goals set and the procedures to follow up and ensure the fulfilment of managerial requirements.

\section{Aligning organisational structures - redesigning to support agile ways of working}

Currently the nodes ${ }^{3}$ deliver each week a new version of their software to us, so that we can integrate. And what is a huge problem for us in our organisation - which I think is a problem in most organisations - is that we have kind of a wall between organisational parts, they deliver and then they think everything is done. But that is when the big problems come. So this concept of cross-functional teams, which we are trying, it's all about the same team doing these activities, so that there is no wall in between. You really want to get to the point where these cross-functional teams have a multinode-feature ${ }^{4}$ that crosses over to many nodes, and that they actually take it through the entire development and then actually test it, take responsibility for testing it in the network environment too. $(\mathrm{H})$

We are making a big change compared to what we have today. Today our organisation is fairly silo-based, where we have clear ownership of operations and the products are very attached to the organisation. Now we are trying to make a more horizontal organisation that would support modern ways of working more and force cooperation. (C)

What I have learnt during the year has been that it is an uphill battle to change culture and mind-sets in something that has gone on for so long. Therefore it is of great value to me to change the [organisational] structure, to change what may be safe, familiar and what you hold on to. Now we create something new. (A)

The above quotes from three managers exemplify the fundamental restructuring of the Zeta unit that took place during the latter period of our interviewing. As the last quote shows, this had followed a period where the middle managers had struggled to influence people's mindsets and create new habits to make people, including themselves, work together more. More demanding and formal organisational restructuring was now regarded as necessary to really influence mind-sets and ways of working. This was done, as in the first case above, through reorganising the composition of teams and where they belonged, which was in accordance with the new agile ways of working. The second quote relates to a situation where a change of mind-set was not enough and the middle managers collaborated to find an entirely new organisational structure that they described as bold and supportive to modern (agile) work, as it was designed to force sub-units into cooperation.

As a part of their work, the managers occasionally redesign the organisational structures of their units to better accomplish the goals that are set. The redesign of organisational structures was, at this time, assumed to be an attempt to force people into new thinking, create new energy and new ways of acting, and prevent stagnation. Thus, redesigning was here used as a force for learning.

\section{Freeing structures}

The alignment of structures contrasted with the freeing of structures. Acts of influence related to the freeing of structures could either concern social structures and a creation of action space that afforded autonomy to people, or mean that organisational structures were broken up or deliberately disregarded.

\footnotetext{
${ }^{3}$ A way of naming a special kind of organisational unit.

${ }^{4}$ Feature here refers to the software services that are developed.
} 
Freeing social structures - allowing and creating space for action

I've had a project leader whose approach was a bit unorthodox, not so much by the book, goes his own way, perhaps has not always kept everyone informed, but achieved tremendous results. There I have had to put out fires afterwards, explain, clean up, handle it. At the same time I let him run with it, as it was so important to reach this target date. $(\mathrm{G})$

And we have a pre-meeting on Thursday mornings. We have it every Thursday, it is a bit of free preparation and reflection about how we ... what is important and how to drive it. It is both content and tactics, you could say. (B)

What we did for two days in October here is probably also characteristic of today. There are some things that you can watch on YouTube. I received some link, someone who explains 'What drives people? Is it the salary? Or are there people who do things for the common good or for the cause itself?' As a human being you want to learn new things, you want to develop and not sit in a cage and do as you've been told. Also pure hearsay, as Google and some other companies have done, that you are allowed to do things your own way a bit. And then I said 'Let the chips fall where they may, let's try. How else will we know?' (I)

The above quotes concern three managerial attempts to influence, and they exemplify a variety of situations where managers either allow, or strive to create action space that affords autonomy to people. The first quote illustrates how a manager allows individual autonomy, despite the fact that it sometimes collides with both rules and people and gives this manager extra work. In this organisation, formal rules thus appear subordinate to goals; this informal rule says that critical customer situations are solved by heroes that succeed despite impossible demands. The second quote describes that some managers wanted to free themselves from the formality of regular meetings, and therefore created an informal arena for them to meet in on a regular basis. The third quote originates from a manager who, despite deadlines and arduous timeframes, made the decision to free all the staff of the sub-unit for two full days, during which time they were actually forbidden to work with regular tasks and were instead given space to do whatever they liked, as long as they were at the workplace and shared their experiences afterwards.

Thus, contrary to making demands to influence the work carried out, managers actually made space for others. Overall, this kind of act of influence can be described as cases where managers, when making space, advocate both high levels of involvement and autonomy instead of control. Making space can also involve the creation of new meeting spots to stimulate new patterns of interaction and the sharing of experience. Contrary to designing structures for alignment, managers here acted with an intention to design social structures that gave space for the emergence of new ways of working based on what others in the organisation found appropriate.

\section{Freeing organisational structures - breaking up or intentionally disregarding}

A rather bold suggestion, we really break up all the structures and build it on another level. We have had big heavy projects, now we want small teams that work and drive parts of the development and so we compose them and try to broaden our responsibility, with that we become a bit more effective/efficient. (C)

It was really that we short-circuited all formal lines of decision. [...] so that it was only these three who said 'Now we go. Now we don't. This we run, kick off.'. And that meant that we took away all formal decision-making bodies, and said that it was three people who ran it. This annoyed a lot of people, but was damn effective I can say. And this resulted in that we made it. (E) 
The projects have their own pages uploaded, and this is common access for everyone. We have all processes accessible this way [...] over the intranet. I think people use it a lot. If that were not the case, you would not be able to make quick deliveries. In principle all information is available to all. We have exactly the same developmental environment here and in Hungary. It looks exactly the same as well, so there are sort of no differences, rather we run exactly. It is also a way to communicate code ... Everything is directly identical. (F)

The above quotes from three managers exemplify cases where established organisational structures were deliberately set aside. The first concerns a complete break with the existing principle of organising the whole Zeta unit. Large projects, safely run by senior appointed people, were to be replaced by small empowered teams to increase effectiveness; but there were also voices that criticised the changes and warned of the high risks of not maintaining deliveries to important customers. The second situation relates to one of many pressurised periods, when the organisation had to stretch its limits to complete work within impossible timeframes to retain its customer. Here, the key players set formal decision-making lines aside and three people took the lead in securing developmental deliveries, making their own tradeoffs concerning quality in deliveries. Finally, the third quote is an example that shows how access to a developmental environment was afforded without the restriction of intraorganisational boundaries or national borders.

That managers dared to abandon pre-decided rules and systems - not only by allowing space within structures, but also by actually breaking up or deliberately disregarding structures - is part of how they attempted to influence work. By freeing structures, the managers created temporary 'task force' units to solve critical situations within short and sharp deadlines, where the ordinary organising of work was not sufficient to deal with the situation.

\section{Discussion}

The aim of this paper is to contribute understanding about learning-oriented leadership as integrated in managers' daily work. In contrast to much previous research, our focus is not on direct face-to-face communication. Rather, our focus is to analyse managers' efforts to influence how work is carried out, using indirect pedagogic interventions (Döös \& Ohlsson, 1999) as our analytical tool. With our emphasis on learning as experiential (Kolb, 1984), work-integrated (Ellström, 2001) and coming as an inherent part of one's daily work (Döös, 2007), the logical premise is that learning takes place as a by-product of action. Thus, it becomes relevant to understand how managerial work, when conceptualised as learningoriented leadership, covers a repertoire of acts of influence that create different types of learning conditions. The use of learning theory as a basis when analysing managers' stories has been decisive in expanding the understanding of learning-oriented leadership beyond communication with single individuals. Taking a different perspective creates another understanding that goes beyond the previous research, where beliefs about how to intentionally facilitate learning are the centre of attention (e.g., Beattie, 2006; Doornbos et al., 2004; Ellinger, 2005). As the study relies on analytical generalisation (Firestone, 1993; Yin, 1989) within a chosen theoretical perspective (Döös \& Wilhelmson, 2014) it contributes the learning-oriented leadership concept to theory on experiential (Dixon, 1994; Döös et al., 2015; Döös \& Wilhelmson, 2011; Kolb, 1984; Ohlsson, 2013), work-integrated learning (Ellström et al., 2008; Ellström, 2001). 
The theoretical body of literature on learning-oriented leadership is limited as the concept is relatively new. Some other concepts may be regarded as conceptually related to it, e.g., the learning-committed leadership (Ellinger, 2005), leaders as enablers of workplace learning (Warhurst, 2013), managers as facilitators of learning (Ellinger et al., 1999) or leaders as facilitators of learning (Wallo, 2008). The difference is that these related concepts all focus on the intentional facilitation of learning. Our empirical analysis shows, when expanding learning-oriented leadership analysis to include managers' daily work, that acts of managerial influence affect learning conditions far beyond the face-to-face communication as described by, for example, Beattie's (2006) hierarchy of facilitative behaviours. The facilitation of work-integrated learning, therefore, needs to be understood in a wider sense than the intentional facilitation of learning. The use of the concept of indirect pedagogical interventions in our analysis points to an understanding of learning conditions in a wider, collective sense, both in terms of the aligning and freeing of social and organisational structures. This study highlights the fact that managers' acts of influence on social and organisational structures are pedagogic in their consequences. Thus, managerial influence becomes pedagogic, even if there is no learning intention. In this way, we have addressed a gap in the previous research literature about how managers' work can influence learning. Furthermore, previous research on managerial work has not explicated the relationship to work-integrated learning (see e.g., Tengblad, 2012).

It became clear that managers did use a number of ways to influence working conditions in the organisation. In the studied case of influence, which largely concerned the task of influencing during a period of organisational change, our interpretation is that the managers beyond direct communication - worked through a combination of aligning and freeing social and organisational structures. See Table 1.

Table 1. Four categories of learning-oriented leadership based on indirect pedagogic interventions.

\section{Aligning structures}

- Social structure alignment:

setting requirements to influence ways

of working

- Organisational structure alignment: redesigning to support agile ways of working

\section{Freeing structures}

\section{- Social structure freeing:}

allowing and creating space for action

- Organisational structure freeing: breaking up or intentionally disregarding structures

Thus, this study has identified two qualitatively different routes that managers use and that change contextual conditions for work-integrated learning: one aligning, that narrows organisational members' discretion; and one freeing, that widens their discretion. Both were empirically found to concern social as well as organisational structures. Combining these with the direct pedagogic interventions that managers also work with points to a repertoire of acts that are used in organisations' change endeavours. The middle managers in this study worked to create the conditions for both autonomy and integration of organisational members (Backström, 2013). As the empirical examples indicate, alignment was built on fixed views of 
objectives, trust in predetermined organisational goals and procedures, and on control of the interpretations of objectives. Thus, limiting the degrees of freedom in people's discretion (Ellström, 1992). By contrast, the freeing of structures was built on confidence in the emerging competence, and a high level of involvement of others. In these cases, the degree of people's discretion was increased. It involved the facilitation, empowerment and authorisation of organisational members, affording discretion, distributing leadership, and trusting the outcome. Here, learning is a means to support the competitiveness of the company.

\section{Limitations of the study}

This paper does not aim to give an answer to the question of whether there are successful learning results from the managers' influencing activities. Although the relationship between acts of influence and learning outcomes was not studied here, we occasionally had powerful indications that this was the case when somebody acted in truly new ways. What we studied concerned how managers' descriptions of their acts of influence may be understood as learning-oriented leadership. Also, it is not possible to be certain that the managers actually acted as they described. However, in this case, the trustworthiness is regarded as good as there is concordance in the data corpus - different people told similar stories and gave similar examples of concrete changes that had been carried out, as well as new organisational plans and structures that were introduced and so on. We also participated in regular meetings and were able to observe some of their doings. The team-based systematic analysis work can be described as a researcher triangulation, thereby reinforcing the validity of our analysis (see Döös \& Wilhelmson, 2014 for intersubjective qualities in data analysis).

\section{Conclusions and implications for practice and future research}

In this paper, we have presented empirical illustrations of how managerial work has an impact on the learning conditions of an organisation, even when this isn't the primary intention. A lot of responsibility is placed on the shoulders of managers, and HR-related aspects such as being learning-committed (Ellinger, 2005) or coaching for learning, run the risk of being regarded as side activities. However, managerial work that creates conducive conditions for continuous learning and development doesn't need to be an activity on its own; on the contrary, as revealed in this paper, learning-oriented elements can be integrated into other aspects of managerial work as managers' acts of influence also can be understood as expressions of different kinds of pedagogic intervention. Due to the position and power that managers often have, they play a highly important role in the creation of conditions for work-integrated learning. As this study shows, learning-oriented leadership does not necessarily imply additional duties for managers; it is rather something that can be more or less exercised as a part of managers' everyday work. Also, other kinds of acts of influence than those presented above certainly exist within managerial work. However, the main point here is to give examples of managers' intentional interventions in how work is carried out and to point to the understanding that such activities have an impact on the conditions for work-integrated learning. The study contributes an alternative way of thinking about how work conditions are influenced that impact on learning in organisations. Learning-oriented leadership is a matter of competence, and therefore it is also something that can be extended and developed. Skills in managing work-integrated learning as a by-product can then be seen as a strategic asset. Thus, 
managers may not have to do more than they already do, but they may need to understand the learning consequences of those acts. These findings have important practical implications as they can include the daily tasks of managerial work.

\section{Implications for practice}

In order to have an influence on work-integrated learning, we propose that managers rely on a mix of aligning and freeing approaches; that is, managers may profit from being aware of the fact that their daily, often event-driven leadership (Holmberg \& Tyrstrup, 2012) can be a significant force in the creation of a learning-conducive environment. Why, then, is this important? From the experiential learning theory-based standpoint (Döös \& Ohlsson, 1999; Kolb \& Kolb, 2010; Kolb, 1984) that the carrying out of tasks also involves learning, there is value in seeing intentional managerial influence as learning-oriented leadership, since this opens up a variety of ways to promote what is learnt and the quality of the content of what is learnt. The spectrum of narrowing/widening discretion, through either the aligning or freeing of structures, affords managers a toolbox of acts of influence to choose from according to the situation and task purpose. It is important here to understand that the acts of influence do not classify people; rather, the middle managers act differently in different situations, and the situated usefulness of the different categories of learning-oriented leadership also emerge in communication between managers. Being aware of the learning implications of managers' organising of work affords opportunities for managers to make more knowledgeable interventions. If managers learn to be aware of the ongoing learning processes among their staff, they may use social and organisational structuring in a more conscious and competent way to support learning and development.

\section{Future research}

The software communication industry is highly exposed to fast technological change and has to continuously adapt mind-sets and ways of working to stay competitive. An issue for future studies is to see whether the identified categories of learning-oriented leadership are also to be found in other lines of business. The freeing of structures, as a means to bring about creativity in a complex task and enhance competitive power, may be particularly important to study in more detail. Moreover, the categorisation of the managerial acts of influence detected in this study may be used as a basis for future research on the indirect side, which has been somewhat neglected in previous research. Ellström (2011) discusses structural and subjective conditions for developmental learning as being either constraining or enabling. On the basis of this study, we suggest a continued focus on the enabling side as containing both aligning and freeing mechanisms. As managers in many organisations struggle with their attempts to change things, it may also be possible to use that will and energy to understand how this relates to the influence of work-integrated learning. Further studies may reveal whether this is a way to circumvent the hindrances or negative contextual factors identified by, for example, Ellinger and Cseh (2007) when facilitation of learning is researched as a separate task that people may find difficult or uninteresting to carry out. For example, an overwhelming pace of change and a lack of time due to work overload were, in this study, reasons and not hindrances when the middle managers were dealing with a change endeavour that was perceived as necessary for the future of the company. 


\section{References}

Agashae, Z., \& Bratton, J. (2001). Leader-follower dynamics: Developing a learning environment. Journal of Workplace Learning, 13(3), 89-102.

Amy, A. H. (2008). Leaders as facilitators of individual and organizational learning. Leadership \& Organization Development Journal, 29(3), 212-234.

Avolio, B. J., Zhu, W., Koh, W., \& Bhatia, P. (2004). Transformational leadership and organizational commitment: mediating role of psychological empowerment and moderating role of structural distance. Journal of Organizational Behavior, 25(8), 951-968.

Backström, T. (2013). Managerial rein control and the Rheo task of leadership. Emergence: Complexity \& Organization, 15(4), 76-90.

Beattie, R. S. (2006). Line managers and workplace learning. Learning from the voluntary sector. Human Resource Development International, 9(1), 99-119. doi: 10.1080/13678860600563366

Billett, S. (2004). Workplace participatory practices: Conceptualising workplaces as learning environments. Journal of Workplace Learning, 16(6), 312-324.

Boud, D., \& Solomon, N. (2003). "I don't think I am a learner": Acts of naming learners at work. Journal of Workplace Learning, 15(7/8), 326-331.

Braun, V., \& Clarke, V. (2006). Using thematic analysis in psychology. Qualitative Research in Psychology, 3(2), 77-101.

Bredin, K., \& Söderlund, J. (2007). Reconceptualising line management in project-based organisations. The case of competence coaches at Tetra Pak. Personnel Review, 36(5), 815-833.

Dixon, N. (1994). The organizational learning cycle. How we can learn collectively. London: McGraw-Hill.

Doornbos, A. J., Bolhuis, S., \& Simons, P. R.-J. (2004). Modeling work-related learning on the basis of intentionality and developmental relatedness: A noneducational perspective. Human Resource Development Review, 3(3), 250-273.

Döös, M. (2007). Organizational learning. Competence-bearing relations and breakdowns of workplace relatonics. In L. Farrell \& T. Fenwick (Eds.), World Year Book of Education 2007. Educating the global workforce. Knowledge, knowledge work and knowledge workers (pp. 141-153). London: Routledge.

Döös, M., Johansson, P., \& Wilhelmson, L. (2015). Organizational learning as an analogy to individual learning? A case of augmented interaction intensity. Vocations and Learning, 8(1), 55-73. doi: 10.1007/s12186-014-9125-9

Döös, M., \& Ohlsson, J. (1999). Relating theory construction to practice development - Some contextual didactic reflections. In J. Ohlsson \& M. Döös (Eds.), Pedagogic interventions as conditions for learning (pp. 5-13). Stockholm: Department of Education, Stockholm University.

Döös, M., \& Wilhelmson, L. (2011). Collective learning: Interaction and a shared action arena. Journal of Workplace Learning, 23(8), 487-500.

Döös, M., \& Wilhelmson, L. (2014). Proximity and distance: Phases of intersubjective qualitative data analysis in a research team. Quality \& Quantity, 48(2), 1089-1106. doi: $10.1007 / \mathrm{s} 11135-012-9816-y$

Ellinger, A. D. (2005). Contextual factors influencing informal learning in a workplace setting: The case of "reinventing itself company". Human Resource Development Quartely, 16(3), 389-415.

Ellinger, A. D., \& Bostrom, R. P. (2002). An examination of managers' beliefs about their roles as facilitators of learning. Management Learning, 33(2), 147-179. 
Ellinger, A. D., \& Cseh, M. (2007). Contextual factors influencing the facilitation of others' learning through everyday work experiences. Journal of Workplace Learning, 19(7), 435-452.

Ellinger, A. D., Ellinger, A. E., \& Keller, S. B. (2003). Supervisory coaching behavior, employee satisfaction, and warehouse employee performance: A dyadic perspective in the distribution industry. Human Resource Development Quarterly, 14(4), 435-458. doi: $10.1002 / \mathrm{hrdq} .1078$

Ellinger, A. D., Watkins, K. E., \& Bostrom, R. P. (1999). Managers as facilitators of learning in learning organizations. Human Resource Development Quartely, 10(2), 105-124.

Ellström, E., Ekholm, B., \& Ellström, P.-E. (2008). Two types of learning environment. Enabling and constraining a study of care work. Journal of Workplace Learning, 20(2), 84-97.

Ellström, P.-E. (1992). Competence, education and learning in working life. Problems, concepts and theoretical perspectives. Stockholm: Publica. (In Swedish)

Ellström, P.-E. (2001). Integrating learning at work: problems and prospects. Human Resource Development Quarterly, 12(4), 421-435.

Ellström, P.-E. (2010). Practice-based innovation: A learning perspective. Journal of Workplace Learning, 22(1/2), 27-40.

Ellström, P.-E. (2011). Informal learning at work: Conditions, processes and logics. In M. Malloch, L. Cairns, K. Evans \& B. N. O'Connor (Eds.), The Sage handbook of workplace learning (pp. 105-119). London: Sage.

Eraut, M. (2011). How researching learning at work can lead to tools for enhancing learning. In M. Malloch, L. Cairns, K. Evans \& B. N. O’Connor (Eds.), The Sage handbook of workplace learning (pp. 181-197). London: Sage.

Fann, K. T. (1970). Peirce's theory of abduction. Haag: Martinus Nijhoff.

Fejes, A., \& Andersson, P. (2009). Recognising prior learning: Understanding the relations among experience, learning and recognition from a constructivist perspective. Vocations and Learning, 2(1), 37-55.

Firestone, W. A. (1993). Alternative arguments for generalizing from data as applied to qualitative research. Educational Researcher, 22(4), 16-23.

Gibson, J. J. (1979). The ecological approach to visual perception. Boston: Houghton Mifflin Company.

Harman, K. (2011). Everyday learning in a public sector workplace: The embodiment of managerial discourses. Management Learning, 43(3), 275-289.

Hodkinson, P., Biesta, G., \& James, D. (2008). Understanding learning culturally: Overcoming the dualism between social and individual views of learning. Vocations and Learning, 1(1), 27-47.

Holmberg, I., \& Tyrstrup, M. (2012). Managerial leadership as event-driven improvisation. In S. Tengblad (Ed.), The work of managers. Towards a practice theory of management (pp. 47-68). Oxford: Oxford University Press.

Hooijberg, R., Hunt, J. G., Antonakis, J., Boal, K. B., \& Lane, N. (Eds.). (2007). Being there even when you are not: Leading through strategy, structures, and systems: Emerald.

Illeris, K. (2004). A model for learning in working life. Journal of Workplace Learning, $16(8), 431-441$.

Johansson, P. (2011). Learning environments in the workplace. The construction of learning environments in a VET-program from an organizational pedagogical point of view. Stockholm: Department of Education, Stockholm University. (In Swedish)

Kolb, A. Y., \& Kolb, D. A. (2005). Learning styles and learning spaces: Enhancing experiential learning in higher education. Academy of Management Learning \& Education, 4(2), 193-212. 
Kolb, A. Y., \& Kolb, D. A. (2010). Learning to play, playing to learn. A case study of a ludic learning space. Journal of Organizational Change Management, 23(1), 26-50.

Kolb, D. A. (1984). Experiential learning. Experience as the source of learning and development. Englewood Cliffs, NJ: Prentice-Hall.

Koopmans, H., Doornbos, A. J., \& van Eekelen, I. M. (2006). Learning in interactive work situations: It takes two to tango; why not invite both partners to dance? Human Resource Development Quartely, 17(2), 135158.

Larsson, G., Sjöberg, M., Vrbanjac, A., \& Björkman, T. (2005). Indirect leadership in a military context: A qualitative study on how to do it. Leadership \& Organization Development Journal, 26(3), 215-227.

Löfberg, A. (1976). Dwelling formation as a pedagogical problem. On the justification and the possibility of the pedagogical intervention. (Doctoral dissertation, R8:1976), Stockholm University, Stockholm.

Löfberg, A. (1989). Learning and educational intervention from a constructivist point of view: The case of workplace learning. In H. Leymann \& H. Kornbluh (Eds.), Socialization and learning at work. A new approach to the learning process in the workplace and society (pp. 137-158). Aldershot: Avebury.

Macneil, C. (2001). The supervisor as a facilitator of informal learning in work teams. Journal of Workplace Learning, 13(6), 246-253.

Noer, D. (2005). Behaviorally based coaching: A cross-cultural case study. International Journal of Coaching in Organizations, 3(1), 14-23.

Noer, D. M., Leupold, C. R., \& Valle, M. (2007). An analysis of Saudi Arabian and U.S. managerial coaching behaviors. Journal of Managerial Issues, XIX(2), 271-287.

Ohlsson, J. (2013). Team learning: Collective reflection processes in teacher teams. Journal of Workplace Learning, 25(5), 296-309.

Reason, J. (1990). Human error. Cambridge: Cambridge University Press.

Reed, E. (1993). The intention to use a specific affordance: A conceptual framework for psychology. In R. H. Wozniak \& K. W. Fischer (Eds.), Development in context. Acting and thinking in specific environments (pp. 45-76). Hillsdale, New Jersey: Lawrence Erlbaum Associates Publishers.

Schunk, D. H. (2004). Learning theories. An educational perspective (4 ed.). Upper Saddle River: Pearson.

Suchman, L. A. (1987). Plans and situated actions. The problem of human machine communication. Cambridge: Cambridge University Press.

Sundström-Frisk, C. (1996). The human factor. In E. Menckel, B. Kullinger, P.-O. Axelsson \& L.-E. Hallgren (Eds.), Fifteen years of occupational-accident research in Sweden (pp. 75-90). Stockholm: Swedish Council for Work Life Research.

Tengblad, S. (Ed.). (2012). The work of managers. Towards a practice theory of management. Oxford: Oxford University Press.

Wallo, A. (2008). The leader as facilitator of learning at work. A study of learning-oriented leadership in two industrial firms. Linköping University, Linköping.

Warhurst, R. P. (2013). Learning in an age of cuts: Managers as enablers of workplace learning. Journal of Workplace Learning, 25(1), 37-57.

Wilhelmson, L., Johansson, P., \& Döös, M. (2013). Bridging boundaries: Middle managers' pedagogic interventions as technology leaders. In S. Wang \& T. Hartsell (Eds.), Technology integration and foundations for effective leadership (pp. 278-292). Hershey: IGI Global.

Yin, R. K. (1989). Case study research. Design and methods (Vol. 5). Newbury Park, Ca: SAGE Publications. 
Yukl, G. (2002). Leadership in organizations (5 ed.). Upper Saddle River, NJ: Prentice-Hall International, Inc.

Yukl, G. (2009). Leading organizational learning: Reflections on theory and research. The Leadership Quarterly, 20, 49-53. 